\title{
Lifelong Learning Tendencies of Teacher Candidates Studying in Pedagogical Formation Program
}

\author{
Necmi Gökyer ${ }^{1}$, Serkan Bakcak ${ }^{2}$, Nevber Cihangiroğlu ${ }^{2}$, Osman Koçak $^{2}$, Gülden Yilmaz ${ }^{2}$ \\ ${ }^{1}$ Assoc. Prof. Dr. Firat University, Faculty of Education, Turkey \\ ${ }^{2} \mathrm{Ph} . \mathrm{D}$. student at Firat University, Turkey \\ Correspondence: Necmi Gökyer, Assoc. Prof. Dr. Firat University, Faculty of Education, Turkey.
}

Received: September 3, 2018

doi:10.11114/jets.v6i11a.3799

\author{
Accepted: October 27, $2018 \quad$ Online Published: November 29, 2018 \\ URL: https://doi.org/10.11114/jets.v6i11a.3799
}

\begin{abstract}
The purpose of this research is to determine the lifelong learning tendencies of the teacher candidates who are studying in the pedagogical formation program and to compare them according to various variables. In the research, the following questions have been answered: 1 . What is the level of life-long learning tendencies of prospective teachers in the pedagogical formation program? 2. Does the lifelong learning tendencies of students in the pedagogical formation program differ significantly by gender, department, faculty, class levels, location, age, and total monthly incomes of their families? The sample consists of 719 teacher candidates determined by simple random sampling from the groups. Teacher candidates' tendency to life-long learning; in the sub-dimension of motivation in the level of "fits very much", in the sub-dimensions of persistence and deprivation in learning regulation and in the whole scale in the level of "partially fits" and in the sub-dimension of lack of curiosity in the level of "fits very little". Women teacher candidates have a higher level of life-long learning tendencies than men. It has been revealed that the life-long learning tendencies of the graduated teacher candidates differ significantly from the teacher candidates who are studying in the third and fourth grades. The level of life-long learning tendencies of teacher candidates aged 19-21 is lower than those aged 22-24 and 25 and over. It is important that the understanding of lifelong learning is gained in the individuals we have trained in our age.
\end{abstract}

Keywords: pedagogical formation program, candidate teacher, lifelong learning tendencies

\section{Introduction}

Non-formal education is the activities of education, production, guidance and implementation carried out throughout life at various durations and levels in order to provide economic, social and cultural developments in the direction of interests, desires and abilities of the individuals who have never entered the formal education system or are at any stage of the formal education system or are separated or finished this stage (MEB, Regulation on Non-formal Education Institutions, 2010). Lifelong learning is also one of the principles of non-formal education. Lifelong education is a general regulation aimed at restructuring the existing system and developing all potential for education outside the formal education system and is a broad concept covering all types of formal and non-formal educational activities.

The difference of the concept of lifelong learning from the concepts of education which were introduced earlier is that it adopts an individual-centered approach, emphasizes out-of-school learning, changing school roles, reducing the weight of the state in education, strengthening the roles of the social partners and not limiting education in a certain period of time (Güleç, Çelik and Demirhan, 2012). The concept of Lifelong Learning has emerged as a result of people's constant self-renewal and development efforts (Lambeir, 2005). The concept of lifelong learning was used by Grundtvig for the first time in 1800's (Wain, 2000) and was shaped in the concept of "adult education" until the 1970s and is considered as a process emphasizing the importance of vocational education (Aktin Evin Gencel, 2013).

Lifelong learning came to the fore with a presentation entitled "Introduction to Lifelong Learning" presented at the UNESCO Conference in 1970 by Paul Lengrand for the first time as a key concept in educational restructuring. Later, in 1972, the International Education Development Commission published a report entitled "The Present and the Future of World Education" (Polat and Odabas, 2008), which pointed to the necessity of lifelong learning. In the following years, lifelong learning was perceived as a process involving all the formal and informal learning that starts from pre-school age until after retirement period (Güleç, Çelik and Demirhan, 2012, Kıvrak, 2007, Uysal, 2009). In 1976 the UNESCO General Conference adopted the following statement on lifelong learning: "Lifelong education is a general regulation 
aimed at restructuring the existing education system and improving all the potential development outside of the education system. In such an arrangement, men and women will themselves conduct their own training ". There are three basic views in this statement: 1) The whole of the education system will be restructured in such a way that people will learn lifelong. 2. It will benefit as much as possible from the regular education sector. 3) The importance of independent learning and learning to learn will be emphasized (UNESCO, 1976).

Dinevski and Dinevski (2004) define the concept as a process of education that takes place throughout life, such as formal education, non-formal education, vocational education, in-service training without constraints such as location, time, age, socio-economic level. Aksoy (2008) defined the concept as the structured, widespread, lifelong learning activities they attended throughout their lifetime in order to improve their knowledge, skills, attitudes and behaviors and their competencies and the documentation of those events. Lifelong learning refers to various activities carried out to learn from birth to death. "Lifelong learning encompasses all-purpose learning activities, whether organized, widespread or natural, for the purpose of developing knowledge, skills and competences within the context of personal, social, social and / or business life" (Commission of the European Communities, 2000). Lifelong learning also means providing a second possibility for the person through the development of basic skills and offering further learning opportunities (Soran, Akkoyunlu and Kavak, 2006: 2). One of the aims of lifelong learning is to create a learning culture and the other one is to realize the social and economic renewal (Jarvis, 2010: 2012). According to the report prepared by DPT (2001: 10), it is stated that lifelong education has three main purposes. These are creating opportunities for lifelong learning, ensuring personal development of individuals, achieving social integration and ensuring economic growth (DPT Special Commissioner's Report, 2001: 10). Chapman and Aspin (1997) summarize the objectives of lifelong learning under three main headings: 1) to train a high-quality workforce, 2) to provide personal development for a more successful life, and 3) to build a strong society. According to Knapper and Cropley (2000), life-long learners are individuals who plan and measure their own learning, are effective in learning, can gather information from different disciplines when necessary, and can apply different learning strategies in different situations.

The Council of Europe (2007) states that the four main objectives of higher education are (Berganve Damian, 2010; Akt: Günay, 2011): (1) preparation for sustainable employment; (2) preparing life as active citizens in a democratic society, (3) personal development, and (4) preserving and developing a broad and advanced knowledge base through learning, teaching and research. The structure of higher education and related programs should be designed for these purposes. Higher education institutions play an important role in developing the skills and competencies necessary for lifelong learning. The ability of universities to perform this function is closely linked to the importance given to both research activities and general cultural education. On this issue, the education ministers of 29 European countries came together and issued a joint declaration known as the "Bologna Declaration". The Bologna Declaration (1999) emphasizes that life-long learning is an important contributor to higher education, and emphasizes that lifelong learning is an integral part of higher education activities (Diker Çoşkun and Demirel, 2012). Harpe and Radloff (2000) state that university programs for life-long learning need to be organized so that students can control their own learning, decide what they need for learning, why they need it, and engage in research activities they can take responsibility. For this reason, the following characteristics are very important for university education: (1) to carry out student-centered learning; (2) providing an educational environment that focuses on the behaviors and skills that will enable students to learn on their own, both during formal education and after their graduation; (3) accept that the learning takes place in many environments in universities whether academic or non-academic, and even in society, in the workplace and in the family (Knapper and Cropley, 2000).

Soran, Akkoyunlu and Kavak (2006) stated that the function of community services has been added to the teaching and research functions of the universities after the 1950s and that the universities have important roles in acquiring lifelong learning skills. In order for universities to fulfil this function university instructors are expected to have lifelong learning skills and students are expected to design learning environments where they can carry out their own learning by undertaking research responsibility. However, it has been observed that university students are not eager enough to participate in lifelong learning activities, have problems in organizing lifelong learning activities, and lack the necessary enthusiasm for lifelong learning (Diker Çoşkun and Demirel, 2012). In this context, the aim of this research is to determine the lifelong learning trends of the teacher candidates who are studying in different faculties and continue to the pedagogical formation program in the education faculty and compare them according to various variables. The study is limited to the prospective teachers studying in the pedagogy formation program in Firat University. In the research, the following questions have been answered.

1. What is the level of life-long learning tendencies of prospective teachers in the pedagogical formation program?

2. Does the lifelong learning tendencies of students in the pedagogical formation program differ significantly by gender, department, faculty, class levels, location, age, and total monthly incomes of their families? 
3. What is the level of relationship between teacher candidates' lifelong learning tendencies according to subscales?

\section{Method}

In the study aimed at determining the lifelong learning trends of the teacher candidates who are educated in the pedagogical formation program at Firat University Faculty of Education and determining whether they differ according to various variables, scanning model was used among the descriptive research methods. Scanning models are intended to describe the past or present event as it exists. An event, individual or an object is tried to be defined as it is in its own conditions (Karasar, 2009: 77).

\section{Universe and sample}

The research universe constitutes a total of 1100 teacher candidates studying in the pedagogical formation program of Firat University Faculty of Education in the academic year of 2017-2018. The sample consists of 719 teacher candidates determined by simple random sampling from the groups. When the demographic characteristics of the teacher candidates participating in the study are examined; the number of male students was $253(35,2 \%)$ and the number of female students was 466 (64,8\%). According to the department variable, 140 students (19.5\%) in literatüre department, 57 students $(7.9 \%)$ in geography department, 113 students (15.7\%) in history department, 29 students (4.0\%) in foriegn languages department, 95 students $(13,2 \%)$ sociology/philosophy / psychology department, 68 students $(9,5 \%)$ in renewable energy, electricity-electronics, automotive, machinery department, 38 students $(5,3 \%)$ in physics, chemistry, biology and mathematics department, 47 students $(6,5 \%)$ in the department of sports administration, recreation and coaching, 78 students $(10,8 \%)$ in justice, accounting, finance, business, public administration department, 54 students $(7,5 \%)$ in the department of radio, TV, journalism and public relations are in the sample. Of the students, $434(60.4 \%)$ were in the humanities and social sciences, $66(9.2 \%)$ were in the engineering faculties, $38(5.3 \%)$ were in the science faculties, $47(6,5 \%)$ were in the faculty of sport sciences, $78 \%(10.8 \%)$ were in the faculty of economics and administrative sciences, and $56(7.8 \%)$ were in the faculty of communication. Of the students, 512 (71.2\%) were in the 3rd grade, $84(11.7 \%)$ were in the 4th grade and $123(17.1 \%)$ of them are graduates. $475(66,1 \%)$ of the students' families live in the province centre, $130(18,1 \%)$ in the district centre and $114(15,9 \%)$ in the village centre. 238 $(33,1 \%)$ of the students were between the ages of 19-21, $304(42,3 \%)$ between the ages of 22-24 years and $177(24,6 \%)$ between the ages of 25-47. 114 of the students (15,9\%) have total monthly income between 50-460 TRY, $302(42,0 \%)$ are between 470-475 TRY and $303(42,1 \%)$ are between 500-8,000 TRY.

\section{Data collection tool}

As a means of data collection in the survey, the scale called "Lifelong learning tendencies of university students (YBÖEÖ)" developed by Diker Coşkun and Demirel (2009) was used. In the first part of YBÖEÖ there are factual questions and in the second part, there are 27 items to determine the lifelong learning trends of the students. The scale consists of four sub-dimensions. While all the items in the motivation and persistence sub-dimensions are positive; all the items in the dimensions of lack of regulation in learning and lack of curiosity are negative. A high score on motivation and persistence dimensions indicates that the lifelong learning trend is high, a low score in those dimensions indicates that the lifelong learning trend is low. This condition is the exact opposite in the dimensions of lack of curiosity and lack of curiosity in the regulation of learning. In other words, the higher the dimension scores, the lower the life-long learning tendency they have; the lower they are the higher lifelong learning tendency they have. The items of the scale prepared in the Likert type scale are scored in the range of "fits very much (6), fits partly (5), fits little (4), doesn't fit little (3), doesn't fit partly (2) and never fits (1)". On the scale, the items in the subscales of lack of regulation in learning and lack of curiosity are scored inversely. The total score can be taken from the entire scale. The minimum score that can be taken from the scale is defined as $(27 \times 1) 27$ and the maximum score is defined as $(27 \times 6) 162$. In order to determine the reliability of the scale, the internal consistency coefficient was calculated and found to be .89 (Diker-Coşkun and Demirel, 2009). In this study, the internal consistency coefficient of the scale was calculated and found to be .81 . Internal consistency coefficients of subscales of the scale are as follows. The motivation subscale was .76, persistence subscale .86, lack of regulation in learning .81 , and lack of curiosity .90 .

\section{Data Analysis}

The data were analyzed using the SPSS for Windows 21 program. Frequency and percentage values were used to determine the demographic characteristics of the prospective teachers (gender, departments, faculties, classes they studied, the place where the family lived, age, total monthly income). Arithmetic mean and standard deviation values were calculated to determine the level of life-long learning tendencies of teacher candidates. Independent groups t-Test was used to determine whether there was a significant difference between the opinions expressed on the basis of gender and place of living variables. In addition, One Way ANOVA was performed to determine whether there was a significant difference between the views of the students in terms of variables such as the class they study, the departments they study, faculties, age, and total monthly income. Mann Whitney U test was performed for two unrelated samples when the normality assumption was not met. The level of significance of the tests was taken as $0 \& .05$. 


\section{Results}

This section includes findings and interpretations of the scale applied to determine the level of life-long learning trends of prospective teachers in the pedagogical formation program.

1. What is the level of the teacher candidates'tendencies of life-long learning, in the sub-dimensions of the scale and in the whole scale?

Table 1. Lifelong Learning Tendencies of Candidate Teachers

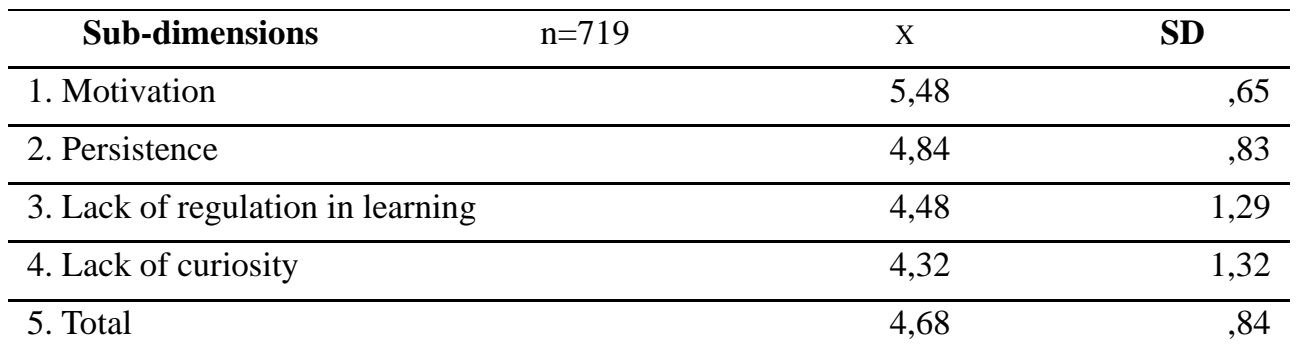

According to Table 1, the teacher-candidates' life-long learning tendencies are "fits very much" in the motivation ( $\bar{x}=5,48)$ subscale, "partly fits" in the subscales of persistence $(\bar{x}=4,84)$ and lack of regulation of learning $(\bar{x}=4,48)$ and in the whole scale $(\bar{x}=4,68)$ and "little fits" in the sub-dimension of curiosity $(\bar{x}=4,32)$.

2. Do the lifelong learning tendencies of the prospective teachers in the pedagogical formation program significantly differ according to the gender variable? The analysis results for the sub-objectives are given in Table 2.

Table 2. T-Test Results According to Teacher Candidates' Views

\begin{tabular}{|c|c|c|c|c|c|c|c|c|}
\hline \multirow{2}{*}{ Sub-dimensions } & \multirow{2}{*}{ Variables } & \multirow{2}{*}{$\mathbf{N}$} & \multirow{2}{*}{$\overline{\mathrm{X}}$} & \multirow{2}{*}{ SS } & \multicolumn{2}{|l|}{ Levene } & \multirow{2}{*}{$\mathbf{t}$} & \multirow{2}{*}{$\mathbf{p}$} \\
\hline & & & & & $\mathbf{F}$ & $\mathbf{p}$ & & \\
\hline \multirow[t]{2}{*}{ 1. Motivation } & Male & 253 & 5,36 & ,79 & 19,180 &, 000 & $-3,348$ &, $001 *$ \\
\hline & Female & 466 & 5,55 &, 54 & & & & \\
\hline \multirow[t]{2}{*}{ 2. Persistence } & Male & 253 & 4,77 & ,89 & 1,614 & ,204 & $-1,632$ & ,103 \\
\hline & Female & 466 & 4,88 &, 80 & & & & \\
\hline \multirow{2}{*}{$\begin{array}{l}\text { 3. Lack of regulation in } \\
\text { learning }\end{array}$} & Male & 253 & 4,21 & 1,38 & 6,373 & ,012 & $-3,981$ & ,000* \\
\hline & Female & 466 & 4,62 & 1,22 & & & & \\
\hline \multirow[t]{2}{*}{ 4. Lack of curiosity } & Male & 253 & 3,95 & 1,43 & 14,529 &, 000 & $-5,350$ & ,000* \\
\hline & Female & 466 & 4,52 & 1,21 & & & & \\
\hline \multirow[t]{2}{*}{ 5. Whole measure } & Male & 253 & 4,46 & ,90 & 11,510 & ,001 & $-5,066$ & ,000* \\
\hline & Female & 466 & 4,80 & ,78 & & & & \\
\hline
\end{tabular}

According to Table 2, between the lifelong learning tendencies of the pedagogical formation program prospective teachers there is a significant difference in the sub-dimensions of motivation (female $\bar{x}=5,55$ and male $\bar{x}=5,36$ ), lack of regulation in learning (female $\bar{x}=4.62$ and male $\bar{x}=4,21$ ), lack of curiosity (Female $\bar{x}=4,52$ and male $\bar{x}=3,95$ ) and in the whole scale ( female $\bar{x}=4,80$ and male $\bar{x}=4,46$ ) according to gender variable. 
Table 3. According to The Gender Variable, MWU Results of The Prospective Teachers' Lifelong Learning Tendencies

\begin{tabular}{|c|c|c|c|c|c|c|c|}
\hline \multirow{2}{*}{ Sub-dimensions } & \multirow{2}{*}{ Work Place } & \multirow{2}{*}{$\mathrm{n}$} & \multirow{2}{*}{ Rank Average } & \multicolumn{4}{|l|}{ MWU } \\
\hline & & & & $\mathrm{U}$ & $\mathrm{p}$ & & Difference \\
\hline \multirow[t]{2}{*}{ 1. Motivation } & Male & 253 & 331,76 & \multirow{2}{*}{51803,500} & & \multirow{2}{*}{,006 } & \multirow{2}{*}{$2-1$} \\
\hline & Female & 466 & 375,33 & & & & \\
\hline \multirow[t]{2}{*}{ 2. Persistence } & Male & 253 & 318,47 & \multirow{2}{*}{48443,000} & \multirow{2}{*}{,000 } & & \multirow{2}{*}{$2-1$} \\
\hline & Female & 466 & 382,55 & & & & \\
\hline \multirow[t]{2}{*}{ 3. Lack of regulation in learning } & Male & 253 & 306,56 & \multirow{2}{*}{45427,500} & \multirow{2}{*}{,000 } & & \multirow{2}{*}{$2-1$} \\
\hline & Female & 466 & 389,02 & & & & \\
\hline \multirow[t]{2}{*}{ 4. Lack of curiosity } & Male & 253 & 307,57 & \multirow{2}{*}{45684,500} & \multirow{2}{*}{, 000} & & \multirow{2}{*}{$2-1$} \\
\hline & Female & 466 & 388,46 & & & & \\
\hline
\end{tabular}

According to Table 3, Mann Whitney U test, which is used in binary comparisons, was used to compare teachers' lifelong learning tendencies by gender variable. When the group average rankings are taken into account, it is seen that the female-candidate teachers' lifelong learning tendencies are higher than the male teacher candidates and the differences are significant.

3. Do the lifelong learning tendencies of teacher candidates significantly differ according to the variable of departments they study? The ANOVA results for the sub-purpose are given in Table 4.

Table 4. ANOVA Results According to Department Variable

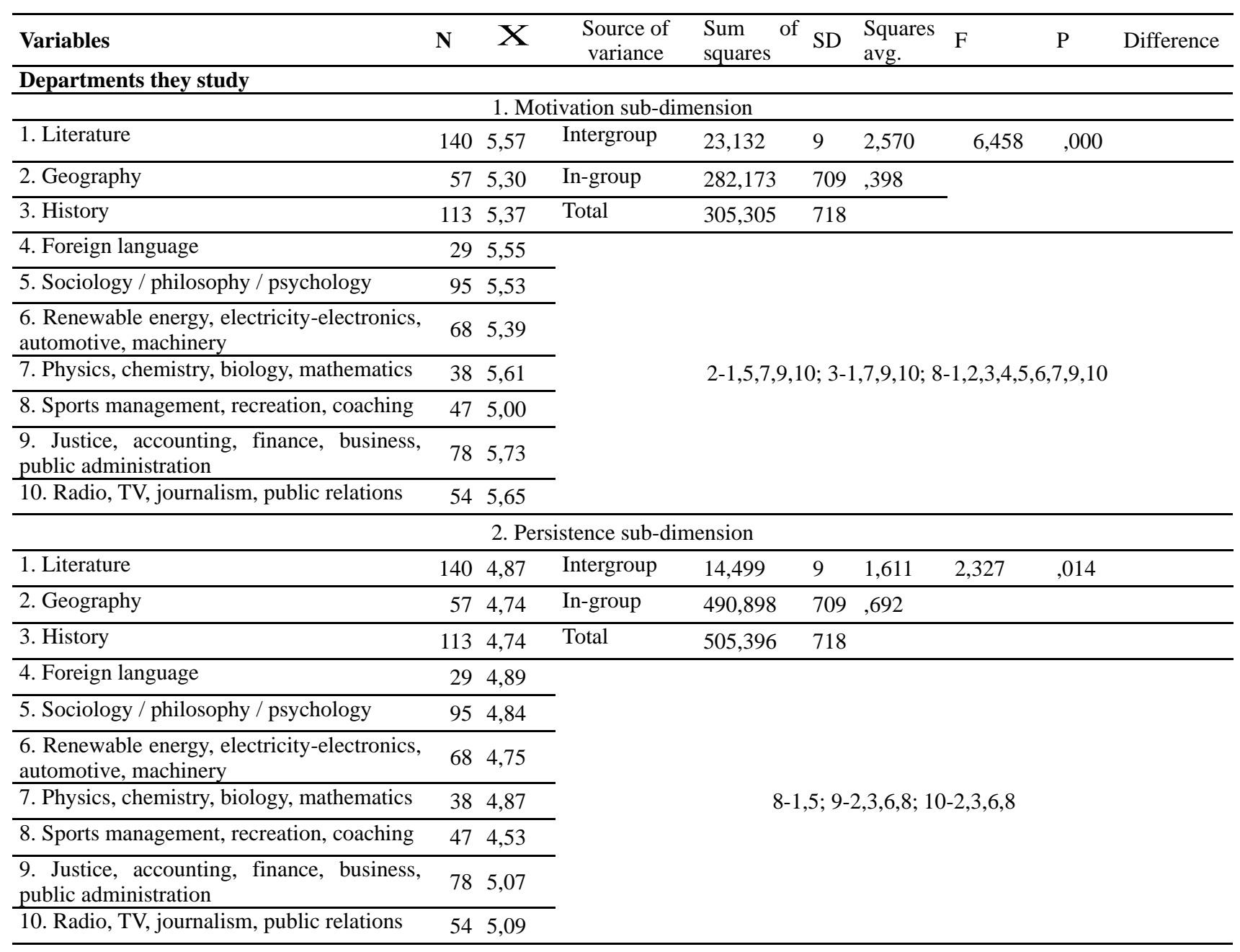


3. Lack of regulation in learning sub-dimension

\begin{tabular}{|c|c|c|c|c|c|c|c|}
\hline 1. Literature & 140 & 4,38 & Intergroup & 157,339 & 9 & $17,48211,770$ & ,000 \\
\hline 2. Geography & 57 & 4,48 & In-group & 1053,076 & 709 & 1,485 & \\
\hline 3. History & 113 & 4,38 & Total & 1210,415 & 718 & & \\
\hline 4. Foreign language & 29 & 4,53 & & & & & \\
\hline 5. Sociology / philosophy / psychology & 95 & 4,73 & \multirow{6}{*}{\multicolumn{5}{|c|}{$3-5,7 ; 5-1 ; 7-1 ; 8-1,2,3,4,5,6,7,9,10 ; 9-1,2,3$}} \\
\hline $\begin{array}{l}\text { 6. Renewable energy, electricity-electronics, automotive, } \\
\text { machinery }\end{array}$ & 68 & 4,50 & & & & & \\
\hline 7. Physics, chemistry, biology, mathematics & 38 & 4,98 & & & & & \\
\hline 8. Sports management, recreation, coaching & 47 & $\overline{2,90}$ & & & & & \\
\hline 9. Justice, accounting, finance, business, public administration & 78 & 4,97 & & & & & \\
\hline 10. Radio, TV, journalism, public relations & 54 & $\overline{4,72}$ & & & & & \\
\hline
\end{tabular}

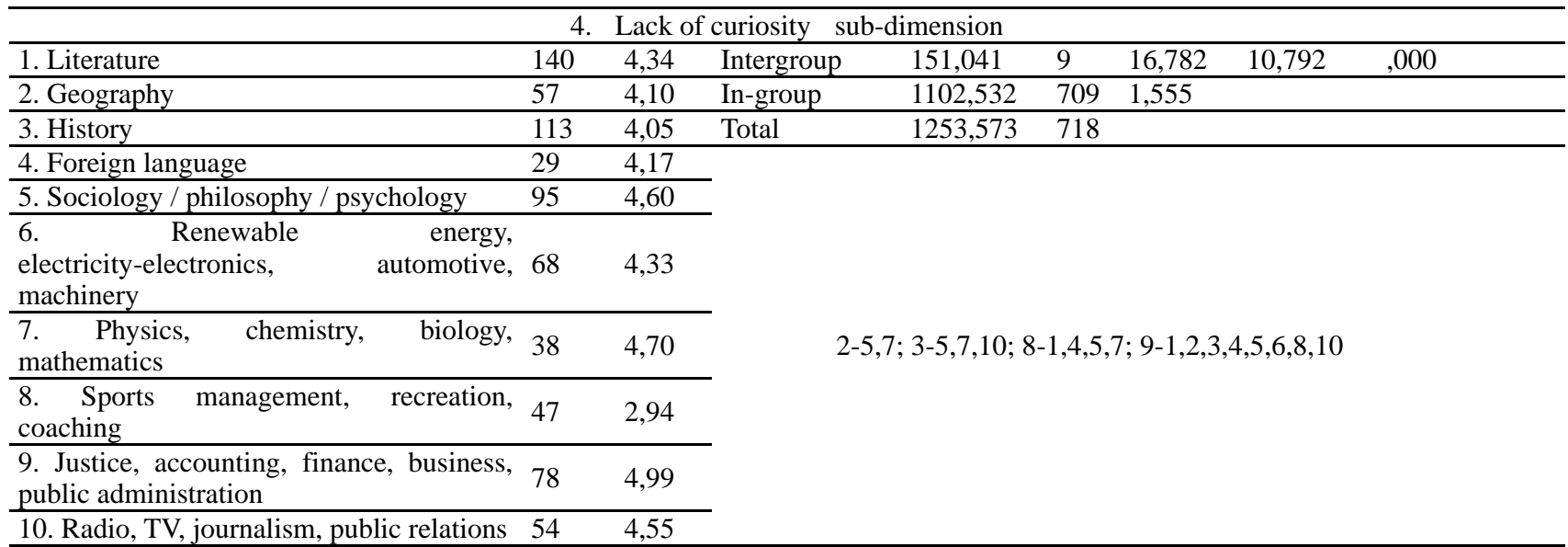

According to Table 4, according to the department variable, the results of the ANOVA made for learning the students' of lifelong learning tendencies show that there is a significant difference for all sub-dimensions. According to the results of LSD test, in motivation sub-dimension, life-long learning tendencies of students in geography $(\bar{x}=5.30)$ are lower than those in literature ( $\bar{x}=5,57)$, sociology / philosophy / psychology ( $\bar{x}=5,53)$, physics, chemistry, biology, mathematics ( $\bar{x}$ $=5,61)$, justice, accounting, finance, management, public administration $(\bar{x}=5,73)$, radio, TV, journalism, public relations $(\bar{x}=5,61)$. Life-long learning tendencies of students who are studying in history $(\bar{x}=5.37)$ are lower than those who study in literature $(\bar{x}=5,77)$, physics, chemistry, biology, mathematics $(\bar{x}=5,61)$, justice, accounting, finance, business, public administration $(\bar{x}=5,73)$ and radio, TV, journalism $(\bar{x}=5,65)$. Lifelong learning tendencies of students who are studying in sports administration, recreation and coaching $(\bar{x}=5,00)$ are lower than those who are studying in geography $(\bar{x}=5,30)$, history $(\bar{x}=5,37)$, foreign language $(\bar{x}=5,55)$, sociology / philosophy / psychology $(\bar{x}=5,53)$, renewable energy, electricity-electronics, automotive, machinery $(\bar{x}=5,39)$, physics, chemistry, biology, mathematics $(\bar{x}=5,61)$, justice, accounting, finance, business, public administration $(\bar{x}=5,73)$ and radio, TV, journalism, public relations $(\bar{x}=5,65)$. In the persistence sub-dimension, life-long learning tendencies of the students who are studying in sports management, recreation, coaching $(\bar{x}=4,53)$ are lower than those who are studying in literature $(\bar{x}=4,87)$ and sociology / philosophy/psychology $(\bar{x}=4,84)$. The lifelong learning tendencies of students who are studying in the department of justice, accounting, finance, administration, public administration $(\bar{x}=5,07)$ are higher than those of students in geography ( $\bar{x}=4.74)$, history $(\bar{x}=4.74)$, renewable energy, electricity-electronics, automotive, machinery $(\bar{x}=4.75)$ and sports management, recreation and coaching $(\bar{x}=4.53)$. Lifelong learning tendencies of students who are educated in radio, $\mathrm{TV}$, journalism, public relations ( $\overline{\mathrm{x}}=5,09)$ are higher than those who have education in Geography $(\overline{\mathrm{x}}=4.74)$, history ( $\overline{\mathrm{x}}$ $=4.74)$, renewable energy, electricity-electronics, automotive and machinery $(\bar{x}=4.75)$ and sports management, recreation, coaching $(\bar{x}=4.53)$. In the sub-dimension of lack of regulation in learning sub-dimension, lifelong learning tendencies of students in history department $(\bar{x}=4.38)$ are lower than those in sociology/philosophy/psychology $(\bar{x}=4,73)$ and those in physics, chemistry, biology, mathematics $(\exists 4,98)$. Lifelong learning tendencies of students who study in sociology/ philosophy/psychology $(\bar{x}=4.73)$ are higher than those who study in literature $(\bar{x}=4.38)$. Life-long learning tendencies of students in physics, chemistry, biology, mathematics $(\bar{x}=4.98)$ are higher than those in literature $(\bar{x}=4.38)$. Lifelong learning tendencies of students who are studying in sports administration, recreation, coaching $(\bar{x}=2.90)$ are lower than 
those who study in literature $(=4,38)$, geography $(=4,48)$, history $(=4,38)$, foreign language $(\bar{x}=4,53)$, sociology / philosophy / psychology $(=4,73)$, renewable energy, electricity-electronics, automotive and machinery $(\bar{x}=4,50)$, physics, chemistry, biology, mathematics $(=4,98)$, justice, accounting, finance, business administration, public administration $(=4.97)$ and radio, TV, journalism and public relations $(\bar{x}=4.72)$. In the sub-dimension of lack of curiosity, students who are studying in geography $(\bar{x}=4,10)$ have a lower lifelong learning tendency than the students studying in the departments of sociology/ philosophy/psychology $(\bar{x}=4,60)$ and physics, chemistry, biology, mathematics $(\bar{x}=4,70)$. The lifelong learning tendencies of the students studying in history $(\bar{x}=4.17)$ are lower than those in the sociology/ philosophy/psychology $(\bar{x}=4.60)$, physics, chemistry, biology, mathematics $(\bar{x}=4,70)$, and radio, TV, journalism and public relations $(=4,55)$. Lifelong learning tendencies of students in sport management, recreation and coaching $(\bar{x}=2.94)$ are lower than those in literature $(\bar{x}=4,34)$, geography $(\bar{x}=4,10)$, history $(\bar{x}=4,05)$, foreign language $(\bar{x}=4,17)$, sociology / philosophy / psychology $(\bar{x}=4.60)$, and physics, chemistry, biology and mathematics $(\bar{x}=4.70)$. Life-long learning tendencies of students who are studying in justice, accounting, finance, management, public administration $(\bar{x}=4,99)$ are higher than those who study in literature $(\bar{x}=4,34)$, geography $(\bar{x}=4,10)$, history $(\bar{x}=4,05)$, foreign language $(\bar{x}=4,17)$, sociology / philosophy / psychology $(\bar{x}=4,60)$, renewable energy, electricity and electronics, automotive, machinery $(\bar{x}$ $=4,33)$, sport management, recreation and coaching $(\bar{x}=2,94)$ and radio, TV, journalism, public relations $(\bar{x}=4,72)$.

Do the lifelong learning tendencies of the teacher candidates significantly differ according to the faculty variables they are studying? The ANOVA results for the sub-purpose are given in Table 5.

Table 5. ANOVA Results According to The Faculty Variable

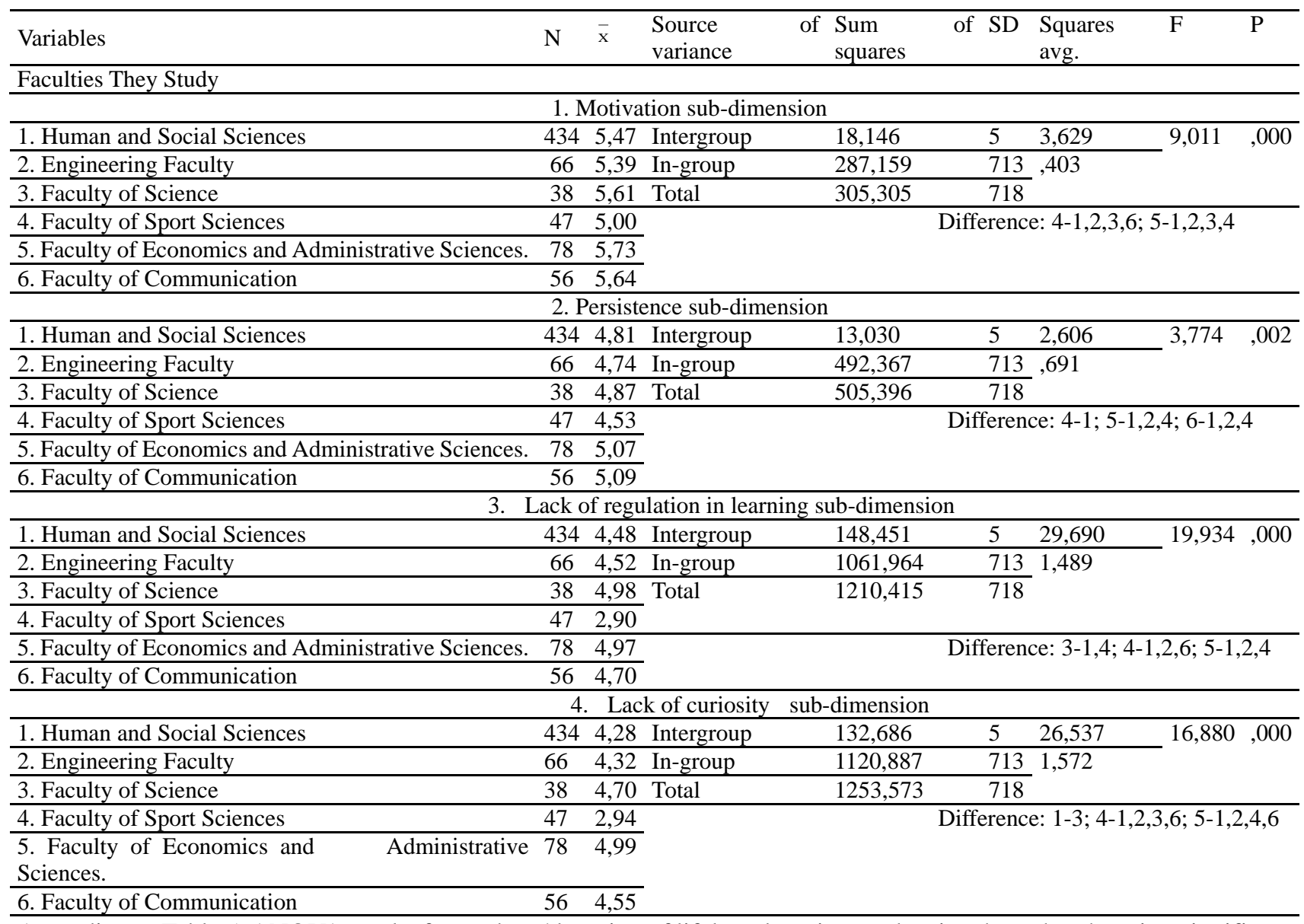

According to Table 5, ANOVA results for students' learning of lifelong learning tendencies show that there is a significant difference for all sub-dimensions, according to the variable of the faculties they study. According to the results of LSD test, in the motivation sub-dimension, the lifelong learning tendencies of the students in the sport sciences faculty $(=5,00)$ are lower than those in human and social sciences $(=5,47)$, engineering faculty $(=5,39)$, science faculty $(=5,61)$ and communication faculty $(=5,64)$. In the same sub-dimension, the lifelong learning tendencies of the students studying in the faculties of economics and administrative sciences $(=5,73)$ are higher than those who study in faculties of human and social sciences $(=5,47)$, engineering $(=5,39)$, science $(=5,61)$ and sport sciences $(=5,00)$.

In the persistence sub-dimension, the lifelong learning tendencies of the students who study in the sports sciences faculty 
$(=4,53)$ are lower than those who study in the humanities and social sciences faculty $(=4,81)$. Lifelong learning tendencies of students studying in the faculties of economics and administrative sciences $(=5,07)$ are higher than those in the faculties of humanities and social sciences $(=4,81)$, engineering $(=4,74)$ and sports sciences $(=4,53)$. The lifelong learning tendencies of the students in the communication faculty $(=5,09)$ are higher than those in the faculties of human and social sciences $(=4,81)$, engineering $(=4,74)$ the sport sciences $(=4,53)$. In the sub-dimension of lack of regulation in learning, the lifelong learning tendencies of students who are studying in Science faculty $(=4,98)$ are higher than those in the humanities and social sciences $(=4.48)$ and those in the sport sciences faculty $(=2.90)$. The lifelong learning tendencies of students in the sport sciences $(=2,90)$ are lower than those in the faculties of humanities and social sciences $(=4,48)$, engineering $(=4,52)$ and communication $(=4,60)$. Lifelong learning tendencies of students studying at the faculties of economics and administrative sciences $(=4.97)$ are higher than those studying in the faculties of humanities and social sciences $(\bar{x}=2,90)$, engineering $(\bar{x}=4,51)$ and sports sciences $(\bar{x}=2,90)$.

In the lack of curiosity sub-dimension, life-long learning tendencies of students who are studying at the faculty of humanities and social sciences $(\bar{x}=4,28)$ are lower than those in the faculty of science $(\bar{x}=4.70)$. The lifelong learning tendencies of students in the sport sciences faculty $(\bar{x}=2.94)$ are lower than those in the faculties of humanities and social sciences $(\bar{x}=4.28)$, engineering $(\bar{x}=4.32)$, science $(\bar{x}=4,70)$ and communication $(\bar{x}=4,55)$. The lifelong learning tendencies of students in the faculty of economics and administrative sciences $(=4.99)$ are higher than those in the faculties of human and social sciences ( $\bar{x}=4.28)$, engineering $(\bar{x}=4.32)$, sports sciences $(\bar{x}=2.94)$ and communication $(\bar{x}$ $=4,55$ ).

Do the lifelong learning tendencies of teacher candidates significantly differ according to the class level they study? The ANOVA results for the sub-purpose are given in Table 6.

Table 6. ANOVA Results According to Class Level Variable

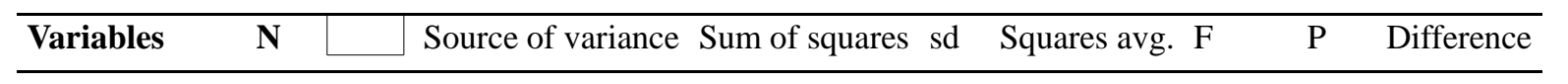

\begin{tabular}{|c|c|c|c|c|c|c|}
\hline \multicolumn{7}{|c|}{ 1. Motivation sub-dimension } \\
\hline 1. Third grade & $512 \quad 5,42$ & Intergroup & 6,777 & 23,389 & $8,128 \quad, 000$ & \\
\hline 2. Fourth grade & 845,58 & In-group & 298,528 & 716,417 & & $3-1,2$ \\
\hline 3. Graduate & 1235,66 & Total & 305,305 & $\overline{718}$ & & \\
\hline \multicolumn{7}{|c|}{ 2. Persistence sub-dimension } \\
\hline 1. Third grade & 5124,76 & Intergroup & 11,011 & 25,506 & $7,973 \quad, 000$ & $3-1,2$ \\
\hline 2. Fourth grade & 845,06 & In-group & 494,385 & 716,690 & & \\
\hline 3. Graduate & 1235,02 & Total & 505,396 & 718 & & \\
\hline \multicolumn{7}{|c|}{ 3. Lack of regulation in learning sub-dimension } \\
\hline 1. Third grade & 5124,31 & Intergroup & 53,887 & 226,943 & $16,680,000$ & \\
\hline 2. Fourth grade & 844,73 & In-group & 1156,529 & 7161,615 & & $3-1,2$ \\
\hline 3. Graduate & 1235,00 & Total & 1210,415 & $\overline{718}$ & & \\
\hline \multicolumn{7}{|c|}{ 4. Lack of curiosity sub-dimension } \\
\hline 1. Third grade & 5124,15 & Intergroup & 55,070 & 227,535 & $16,450,000$ & \\
\hline 2. Fourth grade & 844,58 & In-group & 1198,503 & 7161,674 & & $3-1,2$ \\
\hline 3. Graduate & 1234,84 & Total & 1253,573 & 718 & & \\
\hline
\end{tabular}

According to LSD analysis results, in all the sub-dimensions, according to the class level they study, the scores of lifelong learning tendencies of the graduated teacher candidates differ significantly from the scores of the teacher candidates who study in the third and fourth grades. Graduated students' scores of lifelong learning tendency scores are higher in all sub-dimensions than scores of third and fourth-year students.

Do lifelong learning tendencies of teacher candidates differ significantly according to their ages? The ANOVA results for the sub-objective are given in Table 7. 
Table 7. ANOVA Results According to Age Variable

\begin{tabular}{|c|c|c|c|c|c|c|c|c|c|}
\hline Variables & $\mathbf{N}$ & $x$ & Source of variance & Sum of squares & $\mathrm{sd}$ & Squares avg. & $\mathrm{F}$ & $\mathrm{P}$ & Difference \\
\hline \multicolumn{10}{|l|}{ Age } \\
\hline \multicolumn{10}{|c|}{ 1. Motivation sub-dimension } \\
\hline $1.19-21$ years old & 238 & 5,43 & Intergroup & 2,875 & 2 & 1,438 & \multirow[t]{3}{*}{3,404} & \multirow{3}{*}{\multicolumn{2}{|c|}{$3-1,2$}} \\
\hline $2.22-24$ years old & 304 & 5,46 & In-group & 302,430 & 716 & 4,422 & & & \\
\hline 3.25 years old and older & 177 & 5,59 & Total & 305,305 & 718 & & & & \\
\hline \multicolumn{10}{|c|}{ 2. Persistence sub-dimension } \\
\hline 1.19-21 years old & 238 & 4,69 & Intergroup & 10,783 & 2 & 5,391 & \multirow[t]{3}{*}{7,804} &, 000 & \multirow[t]{3}{*}{$1-2,3$} \\
\hline 2. 22-24 years old & 304 & 4,86 & In-group & 494,614 & 716 & ,691 & & & \\
\hline 3.25 years old and older & 177 & 5,01 & Total & 505,396 & 718 & & & & \\
\hline \multicolumn{10}{|c|}{ 3. Lack of regulation in learning sub-dimension } \\
\hline $1.19-21$ years old & 238 & 4,35 & Intergroup & 23,246 & 2 & 11,623 & 7,010 & ,001 & \multirow{3}{*}{$3-1,2$} \\
\hline 2. $22-24$ years old & 304 & 4,39 & In-group & 1187,169 & 716 & 1,658 & & & \\
\hline 3.25 years old and older & 177 & 4,79 & Total & 1210,415 & 718 & & & & \\
\hline \multicolumn{10}{|c|}{ 4. Lack of curiosity sub-dimension } \\
\hline 1.19-21 years old & 238 & 4,07 & Intergroup & 39,228 & 2 & 19,614 & 11,565 & ,000 & \multirow{3}{*}{$3-1,2$} \\
\hline 2. 22-24 years old & 304 & 4,29 & In-group & 1214,345 & 716 & 1,696 & & & \\
\hline 3. 25 years old and older & 177 & 4,69 & Total & 1253,573 & 718 & & & & \\
\hline
\end{tabular}

According to the age variable, in the motivation sub-dimension, there was a significant difference between the lifelong learning tendencies of the teacher candidates aged 25 and over $(\bar{x}=5.59)$ and those between the ages $19-21(\bar{x}=5,43)$ and 22-24 ( $\bar{x}=5,46)$ according to the one way variance analysis result. The level of lifelong learning tendencies of teacher candidates who are in the age range of 25 and over are higher than those who are between 19-21 and 22-24 years of age. In the sub-dimension of lack of regulation in learning, there is a significant difference between the lifelong learning tendencies of the teacher candidates aged 25 and over $(\bar{x}=4.79)$ and those between 19-21 years $(\bar{x}=4,35)$ and 22-24 years $(\bar{x}=4,39)$. The level of lifelong learning tendencies of teacher candidates who are in the age range of 25 and over are higher than those who are between 19-21 and 22-24 years of age. In lack of curiosity sub-dimension, there was a significant difference between the lifelong learning attitudes of the teacher candidates whose ages were 25 and over $(\bar{x}$ $=4.69)$ and those who were between the ages of 19-21 ( $\bar{x}=4,07)$ and 22-24 years $(\bar{x}=4,29)$. The level of lifelong learning tendencies of teacher candidates who are in the age range of 25 and over are higher than those who are between 19-21 and 22-24 years of age. In the persistence sub-dimension, there was a significant difference between the tendencies of lifelong learning of the candidates who are in the age range of $19-21$ years $(\bar{x}=4,69)$ and those of 22-24 years $(\bar{x}=4,86)$ and 25 years and over $(\bar{x}=5,01)$. The level of life-long learning tendencies of teacher candidates aged 19-21 are lower than those aged 22-24 and 25 and over. According to the results of the analysis, there was no significant difference between the prospective teachers' lifelong learning tendencies according to the monthly total incomes variable.

3. Is there a significant relationship between the motivation, persistence, lack of learning regulation and lack of curiosity sub-dimensions of teacher candidates' lifelong learning tendencies scale?

The findings of the analysis for the sub-purpose are given in Table 8.

Table 8. Relation Between Life-Long Learning Tendencies of Teacher Candidates According to Sub-Dimensions

\begin{tabular}{llllll}
\hline & & 1. & 2. & 3. & 4. \\
\hline 1.Motivation & Pearson Correlation & 1 &, $617^{* *}$ &, $248^{* *}$ &, $360^{* *}$ \\
& Sig. (2-tailed) & &, 000 &, 000 &, 000 \\
& $\mathrm{~N}$ & 719 & 719 & 719 & 719 \\
\hline 2. Persistence & Pearson Correlation & 1 &, $187^{* *}$ &, $382^{* *}$ \\
& Sig. (2-tailed) & &, 000 &, 000 \\
& $\mathrm{~N}$ & 719 & 719 & 719 \\
\hline 3. Lack of regulation in learning & Pearson Correlation & & 1 &, $682^{* *}$ \\
& Sig. (2-tailed) & & &, 000 \\
& $\mathrm{~N}$ & & & 719 \\
\hline 4. Lack of curiosity & Pearson Correlation & & & 1 \\
& Sig. (2-tailed) & & & 719 \\
& $\mathrm{~N}$ & & & \\
\hline
\end{tabular}

**Correlation is significant at the 0.01 level (2-tailed). 
According to Table 8, there appears to be a moderate and positive correlation between motivation and persistence $(\mathrm{r}=$ $0,617, \mathrm{p}<0.01)$. Accordingly, it can be said that as motivation increases, persistence increases. When the coefficient of determination $\left(\mathrm{r}^{2}=0.38\right)$ is taken into consideration, it can be said that $38 \%$ of the total variance in motivation is due to persistence. There appears to be a low and positive correlation between motivation and lack of regulation in learning $(\mathrm{r}=$ $0,248, \mathrm{p}<0.01)$. According to this, it can be said that as the motivation increases, the lack of regulation in learning increases. When the coefficient of determination $\left(\mathrm{r}^{2}=0.06\right)$ is taken into account, it can be said that $6 \%$ of the total variance in motivation is due to lack of regulation in learning. There is a moderate and positive correlation between motivation and lack of curiosity $(r=0,360, \mathrm{p}<0.01)$. According to this, it can be said that as the motivation increases, the lack of regulation in learning increases. When the coefficient of determination $\left(r^{2}=0.13\right)$ is taken into consideration, it can be said that $13 \%$ of the total variance in motivation is due to lack of curiosity. There appears to be a low and positive correlation between persistence and lack of regulation in learning $(r=0,187, p<0.01)$. According to this, it can be said that as the persistence increases, the lack of regulation in learning increases. When the coefficient of determination $\left(r^{2}=0.03\right)$ is taken into account, it can be said that $3 \%$ of the total variance in persistence is due to lack of regulation in learning. There appears to be a moderate and positive correlation between persistence and lack of regulation in learning $(\mathrm{r}=0.382$, $\mathrm{p}<0.01)$. According to this, it can be said that as the persistence increases, the lack of regulation in learning increases. When the coefficient of determination $\left(\mathrm{r}^{2}=0.12\right)$ is taken into account, it can be said that $12 \%$ of the total variance in persistence is due to lack of regulation in learning. There appears to be a moderate and positive correlation between lack of regulation in learning and lack of curiosity $(\mathrm{r}=0.682, \mathrm{p}<0.01)$. According to this, it can be said that as the lack of regulation in learning increases, the lack of curiosity increases. When the coefficient of determination $\left(r^{2}=0.47\right)$ is taken into account, it can be said that $77 \%$ of the total variance of the lack of regulation in learning is due to lack of curiosity.

\section{Discussion and Conclusion}

In this study, it was aimed to determine the lifelong learning tendencies of the teacher candidates who study in the pedagogical formation program. According to the result of this study, the teacher candidates' lifelong learning tendencies are in the level of fits very much in motivation sub-dimension, partially fits in persistence and lack of regulation in learning sub-dimensions and in the whole scale, little fits in lack of curiosity sub-dimension. In the study carried out by Karakuş (2013) which aimed at examining the lifelong learning competencies of the students attending vocational higher schools, it was determined that the lifelong learning competencies of the students were at a good level. Tunca, Şahin and Aydin (2015) found that the lifelong learning expectancy tendencies of teacher candidates were low.

In a study conducted by Ayra \& Kösterelioğlu (2015), in the scale of teachers' lifelong learning tendencies, it was found that the highest mean was in the motivation sub-dimension. In this study, the highest score was also found in the motivation sub-dimension. In a study conducted by Sahin \&Arcagök (2014) on teachers, it was found that teachers' general level of life-long learning competencies was high. However, in the study carried out by Diker Coşkun (2009), it was found that students who participated in research from various universities and faculties had a low level of lifelong learning tendency. The overlap of the results of the surveys may be due to the fact that the surveys are carried out on different groups.

In this study, female-teacher candidates have a higher level of life-long learning tendencies than male-teacher candidates. Female teacher candidates see themselves more positive than male teachers in terms of the statements related to lifelong learning tendencies such as self-improvement, acquiring new knowledge and skills, constantly learning new things, thinking that they will not be discomforted to learn new knowledge and skills in matters not related to their profession. Taking into account the average of the groups, it was determined that the lifelong learning tendencies of the female candidate teachers were higher than the male teacher candidates and the differences were significant. In research conducted by Coşkun \& Demirel (2012), it was determined that the mean scores of female and male students also differ statistically and the difference was higher in the direction of female students. Findings resemble. In the study examining the factors affecting the lifelong learning of university students, Dindar \& Bayraktar (2015) found that gender had no meaningful effect on lifelong learning, but that women's curiosity scores were higher than men's. The levels of similarity of findings are similar. In the study carried out by Tunca, Şahin \& Aydin (2015), it was determined that the lifelong learning tendencies of the teacher candidates did not differ according to gender.

According to the department variable, in the motivation sub-dimension, students in geography, history and sports management, recreation, coaching departments; in persistence sub-dimension, students in sport management, recreation, coaching departments; and lack of regulation in learning sub-dimension, students in the history department have lower life-long learning tendencies than others. In the lack of regulation in learning sub-dimension, the students in the justice, accounting, finance, business, public administration and radio, TV, journalism, public relations and sociology / philosophy / psychology and physics, chemistry, biology, mathematics departments have higher lifelong learning tendencies than others. In the same sub-dimension, the students in the sport management, recreation and coaching departments have a lower lifelong learning tendency than others. In the lack of curiosity sub-dimension, students in 
geography, history and sports administration, recreation and coaching departments have lower life-long learning tendencies. The students in the departments of justice, accounting, finance, management, public administration have higher lifelong learning tendencies than others. In the study carried out by Karakus (2013) which aimed at examining the lifelong learning competencies of the students attending vocational higher schools, no significant difference was found between the departments. In the study carried out by Arsal (2011), which aimed at determining the lifelong learning tendencies of university students, there was no difference between the departments.

In this study, it was determined that, in all the sub-dimensions, scores of lifelong learning tendencies of graduated teacher candidates significantly differ and were high from the scores of the third and fourth-grade teacher candidates, according to the class level of the students. In the study carried out by Karakus (2013) which aimed at examining the lifelong learning competencies of the students attending vocational higher schools, it was found out that as the class level increased, the lifelong learning competencies increased. In the study conducted by Coşkun \& Demirel (2012), statistically significant differences were obtained in favor of fourth-year students. These findings support each other. In the study conducted by Dindar \& Bayraktar (2015), it was determined that class level is not predictive of lifelong learning. Tunca, Şahin and Aydin (2015) found that the teacher candidates in the first grade had a lower lifelong learning tendency than the other classes. In research conducted by Coşkun and Demirel (2012), it was determined that the lifelong learning tendencies of the students were a little higher in the university final grade.

In this study, in the motivation sub-dimension, the level of life-long learning tendencies of the teacher candidates who are in the age range of 25 and above is higher than those in the age range of 19-21 years and 22-24 years. In the lack of regulation in learning sub-dimension, lifelong learning tendencies of teacher candidates whose ages are 25 years and over are higher than those who are between 19-21 years and 22-24 years old. In the lack of curiosity sub-dimension, the lifelong learning tendencies of the teacher candidates whose age is 25 years and over are higher than those in the age range of 19-21 years and 22-24 years. In the persistence sub-dimension, teacher candidates aged 19-21 have lower lifelong learning tendencies than those aged 22-24 and 25 and over. In the study examining the factors affecting the lifelong learning of university students, Dindar \& Bayraktar (2015) found out that age did not predict life-long learning. In this study, according to the analysis results, there was no significant difference between the prospective teachers' lifelong learning tendencies compared to the monthly total incomes and the settlement place where their families live. In the study conducted by Dindar \& Bayraktar (2015), it has been determined that family income is not predictive of lifelong learning.

According to the results obtained from the research, the high scores of the sub-dimensions of lack of regulation in learning and lack of curiosity of the prospective teachers suggest that the tendency of lifelong learning is low. For this reason, students should be trained in acquiring new knowledge and skills when they are not related to their profession, being directed to research, taking the time for personal development, voluntarily participating in courses and seminars, and encouraging them to take advantage of the libraries.

\section{References}

Aksoy, M. (2008). The effects of lifelong learning and career guidance policies on employability: An application on hotel management (Unpublished PhD Thesis). Gazi University Educational Sciences Institute, Ankara.

Arsal, Z. (2011). Lifelong Learning Tendencies of the Prospective Teachers the Bologna Process in Turkey. ATTE Annual Conference, 2011: Teachers' Life-cycle from Initial Teacher Educational to Experienced Professional, Latvia University, Riga 496-509.

Ayra, M., \& Kösterelioğlu, İ. (2015). Relations of Teachers' Perceptions of Vocational Self-Sufficiency of Lifelong Learning Trends. NWSA-Education Sciences, 10(1), 17-28.

Büyüköztürk, Ş. (2016). Scientific Research Methods (21st Edition). Ankara: Pegem Academy.

Coşkun, D. Y., \& Demirel, M. (2012). Lifelong Learning Tendencies of University Students. Hacettepe University Journal of Education, 42, 108-120.

Diker, C. Y. (2009). An Examination of Lifelong Learning Trends of University Students in Terms of Some Variables. Unpublished Doctorate Thesis, Ankara: Hacettepe University, Institute of Social Sciences.

Dindar, H., \& Bayraktar, M. (2015). Factors Affecting Students' Lifelong Learning in Higher Education, International Journal of Lifelong Education and Leadership, 1(1), 11-20. https://doi.org/10.25233/ijlel/2015-v1i1p2

Dinevski, D., \& Dinevski, I. V. (2004). The concepts of university lifelong learning provision in Europe. Transition Studies Review, 11(3), 227-235. https://doi.org/10.1007/s11300-004-0014-z

Evin, G. İ. (2013). Perceptions of prospective teachers towards life-long learning competencies. Education and Science, 38(170), 237-252.

Güleç, İ., Çelik, S., \& Demirhan, B. (2012). What is Lifelong Learning? An Evaluation of Concept and Scope. Sakarya 
University Journal of Education, 2(3), 34-48.

Günay, D. (2011). Problems, tendencies, principles and recommendations in the context of restructuring Turkish higher education. Journal of Higher Education and Science, 1(3), 113-121. https://doi.org/10.5961/jhes.2011.017

Harpe, B., \& Radloff, A. (2000). Informed teachers and learners: Studies in Continuing Education, 22(2), 169-182. https://doi.org/10.1080/713695729

Jarvis, P. (2010). The Routledge international handbook of lifelong learning. USA: Routledge Publishing.

Karakuş, C. (2013). Lifelong learning competencies of vocational school students. Journal of Education and Training Studies, 2(3), 26-35.

Kıvrak, E. (2007). The European Union and lifelong learning policies and employment in Turkey evaluation of relationship. Unpublished Master Thesis. Ankara University Institute of Educational Sciences, Ankara.

Knapper, C., \& Cropley, A. (2000). Lifelong learning in higher education. London: Kogan Page.

Lambeir, B. (2005). Education as liberation: The politics and techniques of lifelong learning, Educational Philosophy and Theory, 37(3), 350. https://doi.org/10.1111/j.1469-5812.2005.00125.x

Ministry of National Education (2010). Regulation on Non - formal Education Institutions. Official Gazette, 21.5.2010 127587.

Polat, C., \& Odabaş, H. (2008). The key to lifelong learning in information society: information literacy. Globalization, democratization and Turkey International Symposium Proceedings (International Symposium on Globalization, Democratization and Turkey) in the Proceedings (596-606). Akdeniz University, Antalya.

Sahin, Ç., \& Arcagök, S. (2014). Investigation of Teachers' Level of Lifelong Learning Competencies in Terms of Variable Variables. Adlyaman University Journal of Social Sciences, 16, 394- 417.

Soran, H., Akkoyunlu, B., \& Kavak, Y. (2006). Life-long learning skills and training programs of trainers: Hacettepe University example. Hacettepe University Journal of Education Faculty, 30, 201-210.

SPO. (2001). Life-long education or non-formal education specialist commission report. Accessed on 04/04/2018. Eduser.com.

Tunca, N., Alkın-Şahin, S., \& Aydın, Ö. (2015). Life-long Learning Tendencies of Pre-service Teachers. Mersin University Journal of the Faculty of Education, 11(2), 432-446. https://doi.org 10.17860 / efd.92694

Uysal, M. (2009). Adult education in developed countries. International Journal of Educational Policies, 3(2), 17-23.

Wain, K. (2000). The learning society: postmodern politics. International Journal of Lifelong Education, 19(1), 36-53. https://doi.org/10.1080/026013700293449

\section{Copyrights}

Copyright for this article is retained by the author(s), with first publication rights granted to the journal.

This is an open-access article distributed under the terms and conditions of the Creative Commons Attribution license which permits unrestricted use, distribution, and reproduction in any medium, provided the original work is properly cited. 